\title{
Oral findings and microbiological evaluation in a case of triple- $X$ syndrome
}

\author{
Kazuhiko Nakano, Kiyoko Tamura, Tomohiro Ogawa, \\ Keiko Kawabata and Takashi Ooshima \\ Department of Pediatric Dentistry, Osaka University Graduate School of Dentistry \\ 1-8 Yamada-oka, Suita, Osaka 565-0871, JAPAN
}

\begin{abstract}
We present a case of a triple-X syndrome in a Japanese girl who was treated from 5Y9M to 14Y6M of age at the Pedodontic Clinic of Osaka University Dental Hospital. At the first examination, multiple dental caries were identified, and a pulpectomy and extraction of the affected teeth were carried out. There were no congenitally absent teeth, including third molars, though the development of permanent teeth was approximately 2 years behind chronological age. At 14Y6M, a PCR analysis of 10 putative periodontopathic bacteria was performed, and all 10 species were found in saliva samples. At the same time, an oral examination revealed that the gingival tissues were highly inflamed with an extremely large amount of calculus, suggesting a risk for the early onset of periodontitis.
\end{abstract}

\author{
Key words \\ PCR, \\ Periodontitis, \\ Periodontopathic bacteria, \\ Retarded eruption, \\ Triple-X syndrome
}

\section{Introduction}

Triple-X syndrome with premature ovarian failure was first described by Jacobs et al. ${ }^{1}$ In 1991, a cytogenetic survey of 14,835 consecutive live births (7,608 males and 7,227 females) in Japan showed that 6.27 per 1,000 had a major chromosomal abnormality, and 0.98 per 1,000 females were diagnosed as having triple-X syndrome ${ }^{2)}$. There were 12 newborns with triple-X syndrome born between 1964 and 1974 and then longitudinally monitored until 15 to 22 years of age for whom medical manifestations until adolescence were recorded in detail ${ }^{3}$. It is thought that problems with triple- $\mathrm{X}$ syndrome are more likely to have verbal processing deficits, lower IQ scores, and a global delay ${ }^{4}$. However, there have been few reports on oral manifestations associated with this syndrome; the only reported findings are that tooth enamel in subjects with this syndrome was thicker than that in normal subjects without a systemic disorder ${ }^{5}$ and that bilateral maxillary second

Received on March 31, 2005

Accepted on July 7, 2005 molars were congenitally missing in one case ${ }^{6)}$.

Periodontitis is rarely seen in children and adolescents except in association with systemic diseases such as neutropenia, Chediak-Higashi syndrome, Papillon-Lefevre syndrome, Down's syndrome, diabetes mellitus, hypophosphatasia, Histiocytosis syndrome, Ehlers-Danlos syndrome, and acquired immunodeficiency syndrome ${ }^{7}$. We previously reported the detection of 10 putative periodontopathic bacteria found in subgingival plaque samples from 144 systemically healthy children without periodontitis using a PCR method ${ }^{8)}$. Capnocytophaga ochracea, Capnocytophaga sputigena, Campylobacter rectus, Eikenella corrodens, and Actinobacillus actinomycetemcomitans were found in approximately half of the samples from children of all ages. Prevotella nigrescens was also frequently detected in samples from older children, whereas Tannerella forsythensis and Prevotella intermedia were detected less frequently, and Porphyromonas gingivalis and Treponema denticola were not found in any of the samples. In a series of studies on Down's syndrome patients, the distribution of periodontal bacteria was evaluated using the same methods, and 
it was revealed that the Down's syndrome patients possessed significantly larger numbers of those species than did generally healthy subjects ${ }^{9}$. In this report, we describe oral manifestations in a Japanese girl with triple-X syndrome and results of microbiological analysis.

\section{Case Report}

\section{Case description and oral findings}

A girl aged 5 years (Y) and 9 months (M) was referred to the Pedodontic Clinic of Osaka University Dental Hospital by her pediatrician for treatment of multiple dental caries. She was reported to be complicated with triple-X syndrome, with develop-
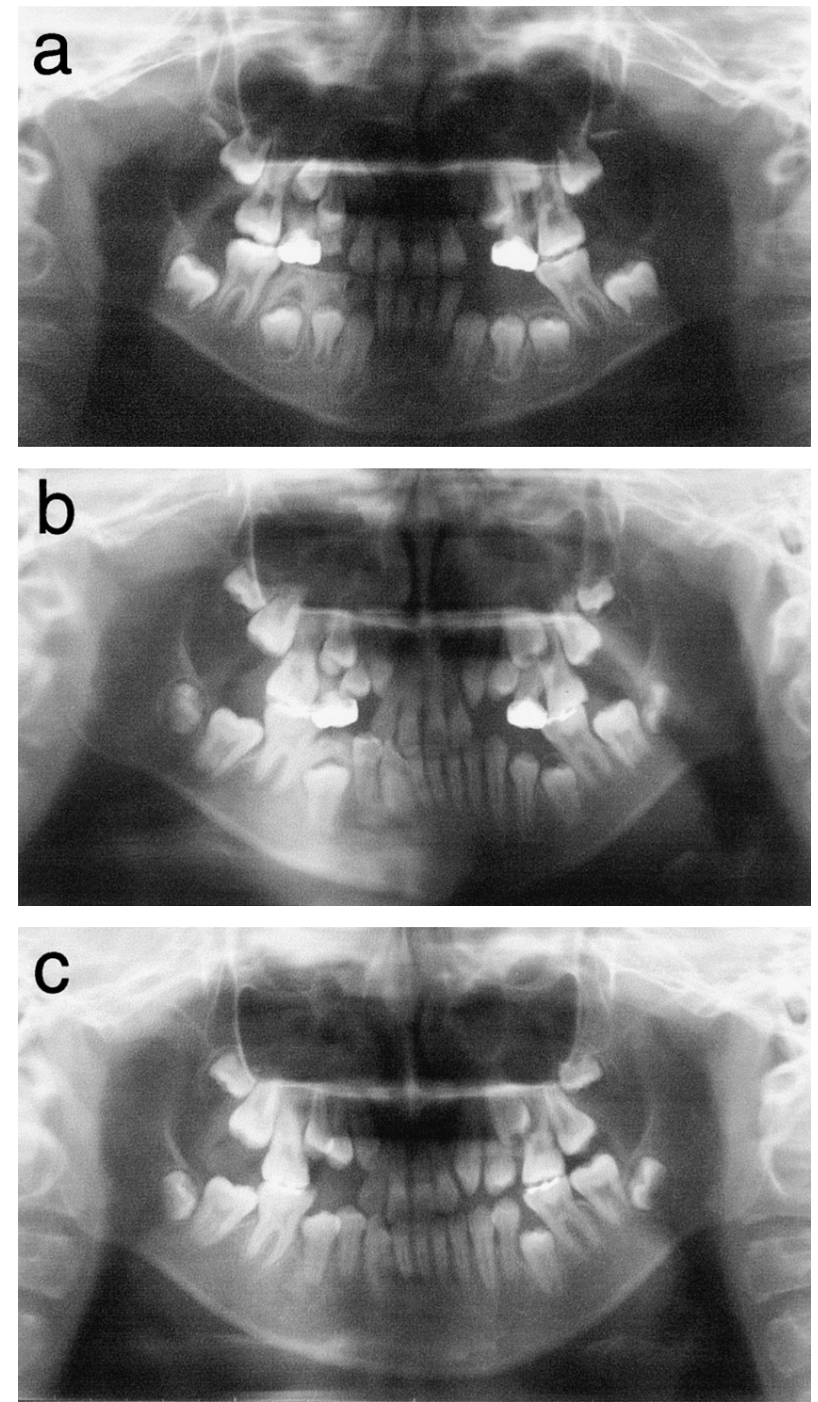

Fig. 1 Orthopantomographs images taken at 10Y2M (a), $13 \mathrm{Y} 1 \mathrm{M}(\mathrm{b})$, and 14Y5M (c) mental retardation. Our initial intraoral examination revealed 11 primary teeth; 9 other primary teeth had been extracted due to dental caries prior to visiting our clinic. According to her mother, she was born after a 40-week gestation without any abnormalities or delivery complications. The first primary tooth had erupted at the age of 12 months. According to the record, her height was $48.0 \mathrm{~cm}$ (approximately 25 th percentile) and body weight was $2,720 \mathrm{~g}$ (approximately 50th percentile) at the time of birth, whereas those at 6 months, and at 1,2, and 5 years of age showed her to be lower than the 10th percentile. At $6 \mathrm{Y} 1 \mathrm{M}$ and $6 \mathrm{Y} 3 \mathrm{M}$, we performed pulpectomies on the maxillary left and right second primary molars, respectively. The maxillary right primary lateral incisor and canine, mandibular right and left primary central incisors, and right primary lateral incisor were also extracted, followed by the application of partial dentures.

At $7 \mathrm{Y} 6 \mathrm{M}$, the mandibular central incisors, lateral incisors, and first permanent molars began to emerge into the oral cavity, and eruption of maxillary central incisors was confirmed at 9Y1M. Since retarded development of all permanent teeth was suspected, orthopantomograph images were routinely taken to evaluate tooth development at 10Y2M, 13Y1M, and 14Y5M (Fig. 1). Although there were no congenitally absent teeth, all teeth showed retarded development. Table 1 shows a comparison of chronological age and dental age, which was calculated by the developmental stage of the permanent teeth in orthopantomograph images by a method described previously ${ }^{10}$. After analyzing 5 images taken from $10 \mathrm{Y} 2 \mathrm{M}$ to $14 \mathrm{Y} 5 \mathrm{M}$, dental age was determined to be approximately 2 years behind chronological age.

Table 1 Comparison of chronological and dental ages of the patient

\begin{tabular}{|c|c|}
\hline $\begin{array}{l}\text { Chronological age } \\
\text { (years) }\end{array}$ & $\begin{array}{c}\text { Dental age } \\
{[\text { mean } \pm \text { SD (years)] }}\end{array}$ \\
\hline $10 \mathrm{Y} 2 \mathrm{M}$ & $7 \mathrm{Y} 9 \mathrm{M} \pm 1 \mathrm{Y} 1 \mathrm{M}$ \\
\hline $11 \mathrm{Y} 11 \mathrm{M}$ & $10 \mathrm{Y} 3 \mathrm{M} \pm$ \\
\hline $13 \mathrm{Y} 1 \mathrm{M}$ & $11 \mathrm{Y} 2 \mathrm{M} \pm \quad 11 \mathrm{M}$ \\
\hline $13 \mathrm{Y} 7 \mathrm{M}$ & $12 \mathrm{Y} 0 \mathrm{M} \pm$ \\
\hline $14 \mathrm{Y} 5 \mathrm{M}$ & $12 \mathrm{Y} 8 \mathrm{M} \pm 1 \mathrm{Y} 3 \mathrm{M}$ \\
\hline
\end{tabular}

Dental age was calculated by evaluating the developmental stages of the permanent teeth by the method described previously ${ }^{10)}$. 


\section{Microbiological evaluation}

An intraoral examination at $13 \mathrm{Y} 9 \mathrm{M}$ revealed that the gingival tissues were highly inflamed with severe deposition of dental calculus on nearly all of the teeth (Fig. 2), and microbiological examination for periodontopathic bacteria using a PCR assay, as described previously ${ }^{11}$, was therefore initiated at the next visit. Expectorated whole saliva was collected from the patient and kept in sterile plastic tubes. The samples were mixed with Chelex 100 (Bio-Rad Laboratories, Hercules, CA, USA) and incubated at $56^{\circ} \mathrm{C}$ for $30 \mathrm{~min}$, followed by boiling at $100^{\circ} \mathrm{C}$ for $10 \mathrm{~min}$. The saliva samples were then centrifuged at $15,000 \mathrm{rpm}$ for $20 \mathrm{~min}$, and the supernatants used as templates for the PCR assays. Subgingival plaque was also collected from all teeth with sterile Gracey curettes and, after gently removing supragingival plaque, the samples were suspended in $1 \mathrm{~m} l$ of sterile saline. The plaque samples in $1 \mathrm{~m} l$ of saline were then centrifuged at $15,000 \mathrm{rpm}$ for $5 \mathrm{~min}$ to pellet the bacterial cells, and bacterial genomic DNA was isolated from the pellets using a DNA isolation kit (Puregene, Gentra Systems, Minneapolis, MN, USA).

PCR was carried out using species-specific primers for the following 10 species of putative periodontopathic pathogens: P.gingivalis ${ }^{12)}, T$. forsythensis $^{13)}$, P. intermedia ${ }^{13)}$, P. nigrescens ${ }^{13)}, C$. rectus $^{13)}$, E. corrodens ${ }^{13)}$, A. actinomycetemcomitans ${ }^{14)}$, C. ochracea $^{14)}$, C. sputigena ${ }^{14)}$, and T.denticola ${ }^{15}$ (Table 2). A ubiquitous primer set that matches nearly all bacterial $16 \mathrm{~S}$ rRNA genes was used as a positive control ${ }^{16)}$. PCR amplification was performed in a reaction mixture containing PCR beads (ReadyTo-Go; Amersham Pharmacia Biotech, Piscataway, NJ, USA).

Table 3 summarizes detection of the 10 periodontopathic bacteria in saliva and dental plaque samples taken from 13Y9M to 14Y6M. Almost all of the bacterial species were detected in both saliva and plaque samples at all 4 examinations. Removal of calculus as well as tooth brushing instruction were performed at each visit. The period between periodical examinations was made shorter
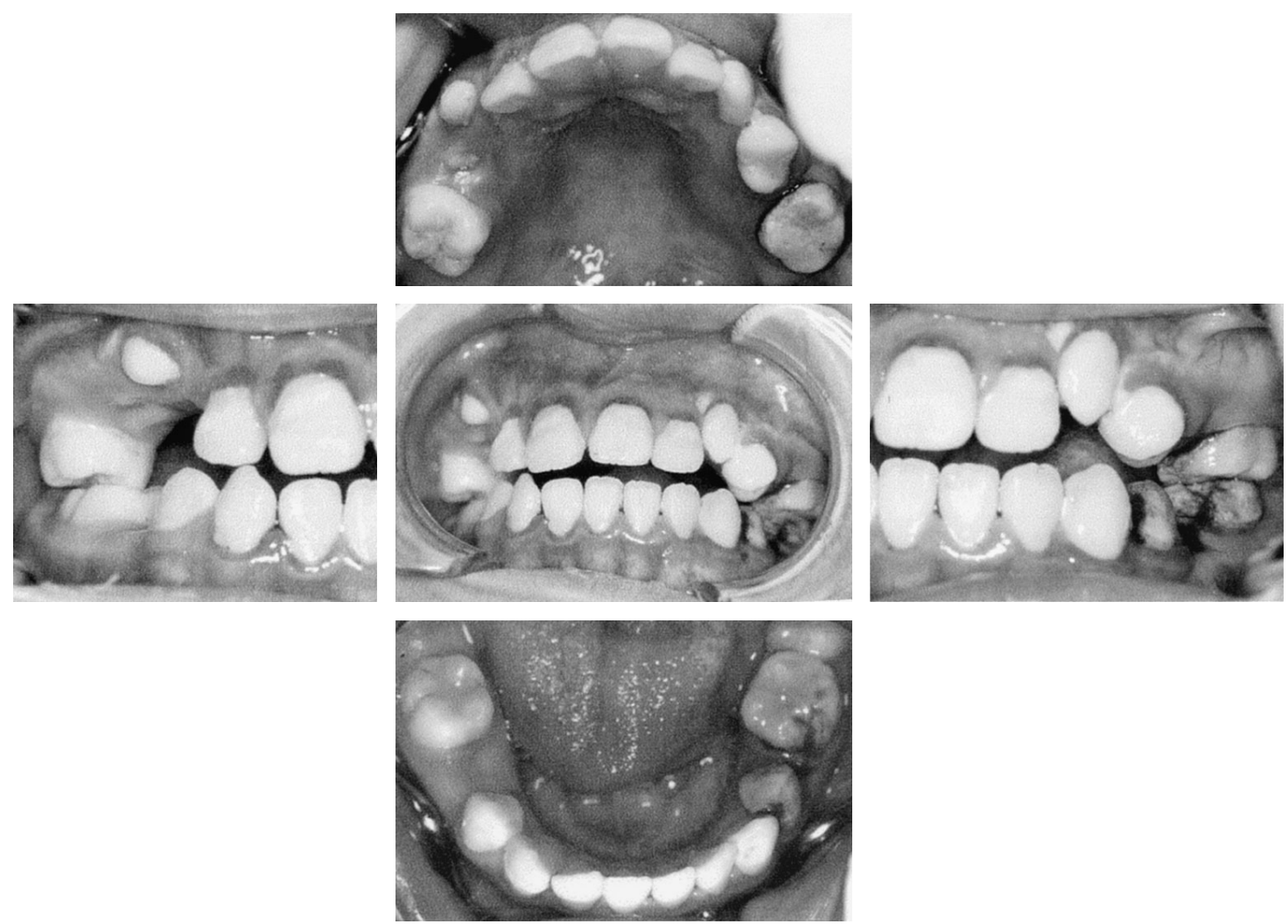

Fig. 2 Intraoral photograph taken at $13 \mathrm{Y} 9 \mathrm{M}$ 
than usual to closely follow the gingival condition.

\section{Clinical examinations and bacterial detection}

At 14Y6M, subgingival plaque samples were taken from 4 representative teeth and bacterial genomic DNA was extracted. PCR analysis was then carried out to determine the presence of the 10 periodontal bacteria, as described above. Clinical parameters, including probing depth, bleeding on probing, pus discharge, tooth mobility, plaque index ${ }^{17)}$ and gingival index ${ }^{18)}$, of 4 representative teeth were also examined. The periodontal pocket depth was measured to the nearest millimeter at 6 points around the circumference of each tooth (mesio-,

Table 2 PCR primers used for detection of 10 putative periodontopathic bacterial species

\begin{tabular}{|c|c|c|c|c|}
\hline Primer set & Sequence $\left(5^{\prime}\right.$ to $\left.3^{\prime}\right)$ & Size (bp) & $\begin{array}{l}\text { Annealing } \\
\text { temperature }\left({ }^{\circ} \mathrm{C}\right)\end{array}$ & Reference \\
\hline $\begin{array}{l}\text { Universal primer } \\
\text { (positive control) }\end{array}$ & $\begin{array}{l}\text { AGA GTT TGA TCM TGG CTC AG } \\
\text { CTG CTG CSY CCC GTA G }\end{array}$ & 315 & 55 & 16 \\
\hline P. gingivalis & $\begin{array}{l}\text { TGT AGA TGA CTG ATG GTG AAA ACC } \\
\text { ACG TCA TCC CCA CCT TCC TC }\end{array}$ & 197 & 60 & 12 \\
\hline T. denticola & $\begin{array}{l}\text { AAG GCG GTA GAG CCG CTC A } \\
\text { AGC CGC TGT CGA AAA GCC CA }\end{array}$ & 311 & 55 & 15 \\
\hline C.ochracea & $\begin{array}{l}\text { AGA GTT TGA TCC TGG CTC AG } \\
\text { GAT GCC GTC CCT ATA TAC GGG G }\end{array}$ & 185 & 55 & 14 \\
\hline C. sputigena & $\begin{array}{l}\text { AGA GTT TGA TCC TGG CTC AG } \\
\text { GAT GCC GCT CCT ATA TAC CAT TAG G }\end{array}$ & 185 & 55 & 14 \\
\hline P. intermedia & $\begin{array}{l}\text { TTT GTT GGG GAG TAA AGC GGG } \\
\text { TCA ACA TCT CTG TAT CCT GCG T }\end{array}$ & 575 & 55 & 13 \\
\hline P. nigrescens & $\begin{array}{l}\text { ATG AAA CAA AGG TTT TCC GGT AAG } \\
\text { CCC ACG TCT CTG TGG GCT GCG A }\end{array}$ & 804 & 55 & 13 \\
\hline A. actinomycetemcomitans & $\begin{array}{l}\text { AGA GTT TGA TCC TGG CTC AG } \\
\text { CAC TTA AAG GTC CGC CTA CGT GCC }\end{array}$ & 593 & 60 & 14 \\
\hline T. forsythensis & $\begin{array}{l}\text { GCG TAT GTA ACC TGC CCG CA } \\
\text { TGC TTC AGT GTC AGT TAT ACC T }\end{array}$ & 641 & 60 & 13 \\
\hline C. rectus & $\begin{array}{l}\text { TTT CGG AGC GTA AAC TCC TTT TC } \\
\text { TTT CTG CAA GCA GAC ACT CTT }\end{array}$ & 598 & 60 & 13 \\
\hline E.corrodens & $\begin{array}{l}\text { CTA ATA CCG CAT ACG TCC TAA G } \\
\text { CTA CTA AGC AAT CAA GTT GCC C }\end{array}$ & 688 & 60 & 13 \\
\hline
\end{tabular}

Table 3 Periodontal bacteria identified by PCR from saliva and plaque samples

\begin{tabular}{lcccc}
\hline \multirow{2}{*}{ Bacterial species } & \multicolumn{4}{c}{ Chronological age } \\
\cline { 2 - 5 } & $13 \mathrm{Y} 9 \mathrm{M}$ & $14 \mathrm{Y} 2 \mathrm{M}$ & $14 \mathrm{Y} 5 \mathrm{M}$ & $14 \mathrm{Y} 6 \mathrm{M}$ \\
\hline P. gingivalis & + & $-(+)$ & $+(+)$ & $+(+)$ \\
T.denticola & - & $-(+)$ & $-(-)$ & $-(+)$ \\
C. ochracea & - & $+(+)$ & $+(+)$ & $+(+)$ \\
C. sputigena & + & $+(+)$ & $+(+)$ & $+(+)$ \\
P. intermedia & + & $-(+)$ & $-(+)$ & $+(+)$ \\
P.nigrescens & - & $-(+)$ & $+(+)$ & $+(+)$ \\
A. actinomycetemcomitans & + & $+(+)$ & $+(+)$ & $+(+)$ \\
T.forsythensis & + & $+(+)$ & $+(+)$ & $+(+)$ \\
C. rectus & + & $+(+)$ & $+(+)$ & $+(+)$ \\
E. corrodens & + & $-(+)$ & $-(+)$ & $+(+)$ \\
\hline
\end{tabular}

Symbols in parenthesis note the absence $(-)$ or presence $(+)$ of periodontal bacteria in dental plaque. Dental plaque was not collected from the subject at the age of 13Y9M. 
mid-, and disto-buccal points and disto-, mid-, and mesio-lingual points) from the gingival margin to the deepest probing point, using a round-ended probe tip of $0.4 \mathrm{~mm}$ in diameter. Bleeding on probing was scored as follows: (+) immediate bleeding on probing or $(-)$ no bleeding. Tooth mobility was scored as follows: (2) moderate mobility $(1-2 \mathrm{~mm})$ in a bucco-lingual direction and (1) slight mobility $(0.2-1 \mathrm{~mm})$ in a bucco-lingual direction or (0) physiological mobility within $0.2 \mathrm{~mm}$. Pus discharge was scored as follows: $(+)$ spontaneous pus discharge or $(-)$ no pus discharge. Table 4 shows the detection of periodontal bacteria and clinical conditions at the 4 representative sites. There were no differences in periodontal pocket depth, bleeding on probing, pus discharge, mobility and plaque index among the 4 representative sites. Three and 8 of the 10 tested bacterial species were identified in samples from the mandibular left canine and maxillary left first molar, respectively, both of which showed a gingival index of 1 , while all 10 species were identified in samples from the maxillary right first molar and mandibular right first premolar, both of which had a gingival score of 2 .

\section{Discussion}

There have been few reports on oral manifestations of triple-X syndrome, and the associated common dental features remain to be elucidated. We know of only one case report describing oral findings of a patient with this syndrome, a 3-year-6-month-old Japanese female who had a single maxillary central incisor and congenitally missing bilateral maxillary second molars ${ }^{6}$. In the present case, there were no congenitally missing permanent teeth, including third molars (Fig. 1), though retarded tooth development was prominent. We speculated that tooth development might be retarded in subjects with this syndrome; however, accumulation of oral findings is required to clarify this speculation.

The other prominent oral manifestations in the present case were severe gingival inflammation and large amounts of calculus on the smooth surfaces of almost all teeth (Fig. 2). The frequency of periodontitis in children and adolescents is known to be extremely low, while gingivitis is often encountered ${ }^{19)}$. The amount of calculus deposition in the present case was significantly greater than that

Table 4 Site-specific clinical gingival condition and detection of periodontal bacteria in subgingival plaque samples

\begin{tabular}{|c|c|c|c|c|}
\hline & \multicolumn{4}{|c|}{ Location } \\
\hline & $\begin{array}{l}\text { Mandibular } \\
\text { left } \\
\text { canine }\end{array}$ & $\begin{array}{l}\text { Maxillary } \\
\text { right } \\
\text { first molar }\end{array}$ & $\begin{array}{l}\text { Maxillary } \\
\text { left } \\
\text { first molar }\end{array}$ & $\begin{array}{l}\text { Mandibular } \\
\text { right } \\
\text { first premolar }\end{array}$ \\
\hline \multicolumn{5}{|c|}{ Gram-negative anaerobic bacteria } \\
\hline$P$. gingivalis & - & + & + & + \\
\hline T. denticola & - & + & + & + \\
\hline C.ochracea & + & + & + & + \\
\hline C. sputigena & + & + & + & + \\
\hline P. intermedia & - & + & - & + \\
\hline P.nigrescens & - & + & + & + \\
\hline A. actinomycetemcomitans & - & + & + & + \\
\hline T.forsythensis & - & + & + & + \\
\hline C.rectus & + & + & + & + \\
\hline E. corrodens & - & + & - & + \\
\hline \multicolumn{5}{|l|}{ Periodontal condition } \\
\hline Pocket depth (mm) & 3 & 3 & 3 & 3 \\
\hline Bleeding on probing & + & + & + & + \\
\hline Gingival index & 1 & 2 & 1 & 2 \\
\hline Plaque index & 3 & 3 & 3 & 3 \\
\hline Mobility & 0 & 0 & 0 & 0 \\
\hline Pus exudate & - & - & - & - \\
\hline
\end{tabular}


in usual cases of gingivitis. It has been shown that several syndromes are associated with periodontitis in children and adolescents; therefore, we speculated that triple-X syndrome might be associated with periodontitis. Our clinical examination revealed that the subject had gingivitis; however, early onset of periodontitis is anticipated unless gingival conditions change.

The results of our microbiological evaluations revealed the presence of all 10 tested periodontal bacteria in saliva samples taken at $14 \mathrm{Y} 2 \mathrm{M}$ and 14Y6M (Table 3). Furthermore, the total number of detected bacteria was extremely high as compared to systemically healthy subjects examined in our previous study, in which the average number of periodontal bacteria detected in children aged 7 to 13 using the same methods as those used in the present study was $3.64^{8)}$. At $14 \mathrm{Y} 6 \mathrm{M}$, plaque samples were taken from 4 representative teeth of the present patient. The number of bacterial species in the sample from the mandibular left canine, which showed slight inflammation, was 3 , while all 10 species were detected in samples from the maxillary right first molar and mandibular right first premolar, which showed severe gingival inflammation (Table 4). We speculated that the number of periodontal bacteria detected might have been correlated with the degree of inflammation in the tested area.

P. intermedia is regarded as a major virulent species for periodontitis, as was indicated by a high detection rate in samples from adults with periodontitis in an earlier study ${ }^{20)}$. Furthermore, P. intermedia has been shown to be strongly associated with periodontitis in childhood ${ }^{21)}$, while it is rarely isolated from healthy children ${ }^{11)}$. As for the onset of periodontitis, analysis of the prevalence and proportion of 7 selected periodontal pathogens in 107 fifteen-year-old Japanese boys and girls led to the conclusion that T.forsythensis and C.rectus are risk markers of the disease ${ }^{22}$. In addition, P. gingivalis, T.denticola, and T.forsythensis have been named the red complex microbial consortium, and their presence together has been shown to be associated with periodontal disease and particularly with deep pocket depths and bleeding on probing ${ }^{23,24)}$. In contrast, analysis of the distribution of the 10 periodontal bacteria that we examined in the present study in systemically healthy children aged 11 to 13 years old showed that $P$. gingivalis and T. denticola were not present in any of the subjects ${ }^{9}$, while both were detected at $13 \mathrm{Y} 9 \mathrm{M}$ in the present patient. In another study, the detection profiles of the same 10 periodontal bacteria in Down's syndrome subjects were classified into 5 clusters, in which cluster 5, used to designate subjects with all species detected, occurred in most of those with severe gingival inflammation as well as those with the highest plaque scores and gingival index ${ }^{9}$. The bacterial detection profile in the present patient resembled cluster 5 , indicating that the subject possesses a high risk for the development of periodontitis. At the time of writing, there has been no demonstration of a correlation between periodontitis and triple- $X$ syndrome. However, we believe that it is necessary to monitor the patient clinically, radiographically, and microbiologically as well as give appropriate instruction and therapy to reduce the risk of onset of the disease.

\section{Acknowledgments}

This study was supported by a Grant-in-Aid for Scientific Research (B) 16390605 from Japan Society for Promotion of Science, and was a part of 21st Century COE entitled "Origination of Frontier BioDentistry" at Osaka University Graduate School of Dentistry supported by the Ministry of Education, Culture, Sports, Science and Technology of Japan.

\section{References}

1) Jacobs, P.A., Baikie, A.G., Brown, W.M., Macgregor, T.N., Maclean, N. and Harnden, D.G.: Evidence for the existence of the human "super female". Lancet 2: 423-425, 1959.

2) Maeda, T., Ohno, M., Matsunobu, A., Yoshihara, K. and Yabe, N.: A cytogenetic survey of 14,835 consecutive liveborns. Jinrui Idengaku Zasshi 36: 117-129, 1991.

3) Linden, M.G., Bender, B.G., Harmon, R.J., Mrazek, D. and Robinson, A.: 47, XXX What is the prognosis? Pediatrics 82: 619-630, 1988.

4) Sybert, V.P.: Phenotypic effects of mosaicism for a 47, XXX cell line in Turner syndrome. J Med Genet 39: 217-220, 2002.

5) Alvesalo, L., Tammisalo, E. and Therman, E.: 47, XXX females, sex chromosomes, and tooth crown structure. Hum Genet 77: 345-348, 1987.

6) Miura, M., Kato, N., Kojima, H. and Oguchi, H. Triple-X syndrome accompanied by single maxillary central incisor: case report. Pediatr Dent 15: 214 217, 1993.

7) Meyle, J. and Gonzales, J.R.: Influences of systemic diseases on periodontitis in children and adolescents. Periodontol 2000 26: 92-112, 2001.

8) Kimura, S., Ooshima, T., Takiguchi, M., Sasaki, 
Y., Amano, A., Morisaki, I. and Hamada, S.: Periodontopathic bacterial infection in childhood. J Periodontol 73: 20-26, 2002.

9) Amano, A., Kishima, T., Kimura, S., Takiguchi, M., Ooshima, T., Hamada, S. and Morisaki, I.: Periodontopathic bacteria in children with Down syndrome. J Periodontol 71: 249-255, 2000.

10) Nakano, K., Matsuoka, T., Takahashi, A., Matsumura, M., Sobue, S. and Ooshima, T.: Delayed development or congenital absence of a single first permanent molar in Japanese child patients. Int J Paediatr Dent 9: 271-276, 1999.

11) Ooshima, T., Nishiyama, N., Hou, B., Tamura, K., Amano, A., Kusumoto, A. and Kimura, S.: Occurrence of periodontal bacteria in healthy children: a 2-year longitudinal study. Community Dent Oral Epidemiol 31: 417-425, 2003.

12) Tran, S.D. and Rudney, J.D.: Multiplex PCR using conserved and species-specific 16S rRNA gene primers for simultaneous detection of Actinobacillus actinomycetemcomitans and Porphyromonas gingivalis. J Clin Microbiol 34: 2674-2678, 1996.

13) Ashimoto, A., Chen, C., Bakker, I. and Slots, J.: Polymerase chain reaction detection of 8 putative periodontal pathogens in subgingival plaque of gingivitis and advanced periodontitis lesions. Oral Microbiol Immunol 11: 266-273, 1996.

14) Conrads, G., Mutters, R., Fischer, J., Brauner, A., Lutticken, R. and Lampert, F.: PCR reaction and dotblot hybridization to monitor the distribution of oral pathogens within plaque samples of periodontally healthy individuals. J Periodontol 67: 994-1003, 1996.

15) Watanabe, K. and Frommel, T.O.: Porphyromonas gingivalis, Actinobacillus actinomycetemcomitans and Treponema denticola detection in oral plaque samples using the polymerase chain reaction. J Clin Periodontol 23: 212-219, 1996.

16) Doungudomdacha, S., Rawlinson, A. and Douglas, C.W.: Enumeration of Porphyromonas gingivalis,
Prevotella intermedia and Actinobacillus actinomycetemcomitans in subgingival plaque samples by a quantitative-competitive PCR method. J Med Microbiol 49: 861-874, 2000.

17) Silness, J. and Löe, H.: Periodontal disease in pregnancy. II. Correlation between oral hygiene and periodontal condition. Acta Odontol Scand 22: 121135, 1964.

18) Löe, H. and Silness, J.: Periodontal disease in pregnancy. I. Prevalence and severity. Acta Odontol Scand 21: 533-551, 1963.

19) Jenkins, W.M. and Papapanou, P.N.: Epidemiology of periodontal disease in children and adolescents. Periodontol 2000 26: 16-32, 2001.

20) Matto, J., Saarela, M., von Troil-Linden, B., Kononen, E., Jousimies-Somer, H., Torkko, H., Alaluusua, S. and Asikainen, S.: Distribution and genetic analysis of oral Prevotella intermedia and Prevotella nigrescens. Oral Microbiol Immunol 11: 96-102, 1996.

21) Okada, M., Hayashi, F. and Nagasaka, N.: PCR detection of 5 putative periodontal pathogens in dental plaque samples from children 2 to 12 years of age. J Clin Periodontol 28: 576-582, 2001.

22) Suda, R., Kobayashi, M., Nanba, R., Iwamaru, M., Hayashi, Y., Lai, C.H. and Hasegawa, K.: Possible periodontal pathogens associated with clinical symptoms of periodontal disease in Japanese high school students. J Periodontol 75: 1084-1089, 2004.

23) Socransky, S.S., Haffajee, A.D., Cugini, M.A., Smith, C. and Kent, R.L. Jr.: Microbial complexes in subgingival plaque. J Clin Periodontol 25: 134-144, 1998.

24) Rocas, I.N., Siqueira, J.F. Jr., Santos, K.R. and Coelho, A.M.: "Red complex" (Bacteroides forsythus, Porphyromonas gingivalis, and Treponema denticola) in endodontic infections: a molecular approach. Oral Surg Oral Med Oral Pathol Oral Radiol Endod 91: 468-471, 2001. 